\title{
Substance Use Previous Occurrence
}

National Cancer Institute

\section{Source}

National Cancer Institute. Substance Use Previous Occurrence. NCI Thesaurus. Code C162326.

An indication or description that a particular substance use event happened in the past. 